\title{
INTERAKSI DIDALAM KELUARGA DENGAN ANAK BERHADAPAN DENGAN HUKUM DI PANTI SOSIAL MASURDI PUTRA BAMBU APUS JAKARTA
}

\author{
Oleh: \\ Febry Hizba Ahshaina Suharto, Budhi Wibhawa \& Eva Nuriyah Hidayat \\ Email: \\ (febryhizba@yahoo.co.id; budhiwibhawa@gmail.com; enuriyah@yahoo.co.id)
}

\begin{abstract}
ABSTRAK, Keluarga merupakan lingkungan kehidupan yang dikenal anak untuk pertama kalinya, dan untuk seterusnya anak banyak belajar di dalam kehidupan keluarga. Oleh karena itu peran, sikap dan perilaku orangtua dalam proses pengasuhan anak, sangat besar pengaruhnya dalam pembentukan dan perkembangan kepribadian anak. Dengan kehadiran seorang anak dalam keluarga, komunikasi dalam keluarga menjadi lebih penting dan intensitasnya harus semakin meningkat, artinya dalam keluarga perlu ada komunikasi yang baik dan sesering mungkin antara orang tua dengan anak. Cukup banyak persoalan yang timbul di masyarakat karena atau tidak adanya komunikasi yang baik dalam keluarga. Dalam kenyataannya, proses interaksi anak dengan orangtua tidak selalu sesuai dengan yang diharapkan dan tidaklah sesederhana yang kita bayangkan dan katakan. Pengasuhan sering dibumbui oleh berbagai hal yang tidak mendukung bagi kemandirian anak, antara lain: sikap dan perilaku orangtua yang tidak dapat menjadi contoh bagi anak-anaknya, suasana emosi anggota rumah tangga sehari-hari yang tidak kondusif, serta interaksi anggota keluarga lainnya yang tidak baik. Dengan situasi seperti itu, maka tidak semua interaksi keluarga terhadap anak efektif, akibatnya, perilaku dan kemandirian anak, tidak sesuai dengan yang diharapkan. Faktor lingkungan, seperti kemajuan teknologi informasi dan globalisasi yang berkembang pesat dewasa ini sangat mempengaruhi nilai dan norma yang berlaku dalam individu, keluarga, dan masyarakat. Hal ini dapat berakibat terjadinya berbagai permasalahan sosial pada anak diantaranya; penyimpangan perilaku baik pada anak maupun pada orang dewasa, seperti tindak kekerasan, pencurian, pelecehan seksual, tawuran dan lain- lain yang menyebabkan anak berhadapan dengan hukum $(\mathrm{ABH})$.
\end{abstract}

\begin{abstract}
ABSTRAC, family is the child's living environment known for the first time, and there is so many things that children learn in their family. Therefore roles, attitudes and behavior of children of parents in the parenting process, a very large influence in the formation and development of the child's personality. With the presence of a child in the family, family communication becomes more important and the intensity should be increased, meaning that in the family there needs to be good communication and as often as possible between parents and children. Quite a lot of problems that arise in the community because of or lack of good communication within the family.In reality, the process of interaction between children and parents are not always as expected and not as simple as we imagine and say. Parenting is often flavored by a variety of things that are not conducive to the child's independence, among other things: the attitude and behavior of parents who can not be an model for their children, the emotional atmosphere of the household members everyday that are not conducive, as well as the interaction of other family members who are not good, With such a situation, it is not all the families of the children's interactions effective, consequently, the behavior and the child's independence, not as expected. Environmental factors, such as advances in information technology and the globalization of today's rapidly growing influence of values and norms that apply in the individual, family, and community. This can result in a variety of social problems in children including; deviant behavior both in children and in adults, such as violence, theft, sexual abuse, brawls and others that causes child against the law.
\end{abstract}




\section{A. PENDAHULUAN}

Permasalahan sosial pada anak diantaranya; penyimpangan perilaku baik pada anak maupun pada orang dewasa, seperti tindak kekerasan, pencurian, pelecehan seksual, tawuran dan lain- lain yang menyebabkan anak berhadapan dengan hukum. Dikatakan penyimpangan sosial karena mengganggu ketertiban orang lain atau masyarakat, merupakan perilaku yang tidak sesuai dengan nilai-nilai kesusilaan atau kepatutan (kemanusiaan), baik dalam sudut pandang moral (agama) secara individual maupun masyarakat. Akibatnya, anak-anak yang berperilaku menyimpang tersebut sering disebut sebagai anak nakal, atau yang yang berhadapan dengan hukum. Anak berhadapan dengan hukum $(\mathrm{ABH})$ meliputi anak yang berkonflik dengan hukum dan anak korban tindak pidana. Tindakan melawan hukum merupakan salah satu bentuk penyimpangan perilaku.

Data Ditjen Pemasyarakatan Juni 2014 menujukan 2.060 anak (1.891 laki-laki, 169 perempuan) ditahan di berbagai institusi penahanan yang tersebar di Indonesia dan masih dalam proses peradilan. Jumlah narapidana anak di Indonesia 3.379 anak (3.095 laki-laki, 284 perempuan) sudah pada proses peradilan dinal (putusan peradilan). Angka ini meningkat dibandingkan populasi tahanan anak pada tahun 2011. Komisi Nasional Perlindungan Anak (LSM Komnas PA) melaporkan bahwa terdapat 1.851 pengaduan anak yang berhadapan dengan hukum (pencurian, kekerasan, pemerkosaan, narkoba, perjudian dan penganiayaan).

Keluarga merupakan lingkungan kehidupan yang dikenal anak untuk pertama kalinya, dan untuk seterusnya anak banyak belajar di dalam kehidupan keluarga. Oleh karena itu peran, sikap dan perilaku orangtua dalam proses pengasuhan anak, sangat besar pengaruhnya dalam pembentukan dan perkembangan kepribadian anak. Di dalam keluarga anak-anak mulai menerima pendidikan yang pertama dan paling utama. Pendidikan yang diterima oleh anak mulai dari pendidikan agama, cara bergaul, dan hubungan interaksi dengan lingkungan. Keluarga merupakan lingkungan sosial yang pertama bagi anak. Dalam lingkungan keluargalah anak mulai mengadakan persepsi, baik mengenai hal-hal yang ada di luar dirinya, maupun mengenai dirinya sendiri. Di dalam keluarga, orangtualah yang berperan utama dalam mengasuh, membimbing dan membantu mengarahkan anak untuk menjadi mandiri dan berperilaku sesuai dengan nilai dan norma yang berlaku dalam masyarakat. Mengingat masa anakanak dan remaja merupakan masa yang penting dalam proses perkembangan fisik, mental dan psikososial, dan sering dikatakan sebagai masa labil dan masih mencari identitas, maka peran orangtua sangat penting.

Dengan kehadiran seorang anak dalam keluarga, komunikasi dalam keluarga menjadi lebih penting dan intensitasnya harus semakin meningkat, artinya dalam keluarga perlu ada komunikasi yang baik dan sesering mungkin antara orang tua dengan anak. Cukup banyak persoalan yang timbul di masyarakat karena atau tidak adanya komunikasi yang baik dalam keluarga. Hubungan yang terjadi di dalam keluarga biasanya dilakukan melalui suatu kontak sosial dan komunikasi. Kedua hal ini merupakan syarat terjadinya suatu interaksi sosial. Artinya, interaksi yang sesungguhnya dapat diperoleh melalui kontak sosial dan komunikasi. Terjadinya interaksi dan komunikasi dalam keluarga akan saling mempengaruhi satu dengan yang lain dan saling memberikan stimulus dan respons. Dengan interaksi antara anak dengan orang tua, akan membentuk gambaran-gambaran tertentu pada masing-masing pihak sebagai hasil dari komunikasi. Anak akan mempunyai gambaran tertentu mengenai orang tuanya. Dengan adanya gambaran-gambaran tertentu tersebut sebagai hasil persepsinya melalui komunikasi, maka akan terbentuk juga sikapsikap tertentu dari masing-masing pihak.

Namun dalam kenyataannya, proses interaksi anak dengan orangtua tidak selalu sesuai dengan yang diharapkan dan tidaklah sesederhana yang kita bayangkan dan katakan. Pengasuhan sering dibumbui oleh berbagai hal yang tidak mendukung bagi kemandirian anak, antara lain: sikap dan perilaku orangtua yang tidak dapat menjadi contoh bagi anak-anaknya, suasana emosi anggota rumah tangga sehari-hari yang tidak kondusif, serta interaksi anggota keluarga 
lainnya yang tidak baik. Dengan situasi seperti itu, maka tidak semua interaksi keluarga terhadap anak efektif, akibatnya, perilaku dan kemandirian anak, tidak sesuai dengan yang diharapkan. Faktor lingkungan, seperti kemajuan teknologi informasi dan globalisasi yang berkembang pesat dewasa ini sangat mempengaruhi nilai dan norma yang berlaku dalam individu, keluarga, dan masyarakat. Hal ini dapat berakibat terjadinya berbagai permasalahan sosial pada anak diantaranya; penyimpangan perilaku baik pada anak maupun pada orang dewasa, seperti tindak kekerasan, pencurian, pelecehan seksual, tawuran dan lain- lain yang menyebabkan anak berhadapan dengan hukum. Kenakalan anak pada era globalisasi saat ini tidak lagi merupakan fenomena sederhana, namun telah meluas menjadi isu yang sangat mengkhawatirkan. Kasus $A B H$ di Indonesia cenderung meningkat dari tahun ke tahun (Sari, 2011, h.8). Perilaku menyimpang yang biasa dikenal dengan nama penyimpangan sosial karena mengganggu ketertiban orang lain atau masyarakat, merupakan perilaku yang tidak sesuai dengan nilai-nilai kesusilaan atau kepatutan (kemanusiaan), baik dalam sudut pandang moral (agama) secara individual maupun masyarakat. Akibatnya, anak-anak yang berperilaku menyimpang tersebut sering disebut sebagai anak nakal, atau anak yang berhadapan dengan hukum. Masalah Anak Berhadapan dengan hukum $(\mathrm{ABH})$ tersebut telah menjadi perhatian Kementerian Sosial RI. Menurut Pusdatin 2009, jumlah anak nakal sebanyak 148.371 jiwa dari populasi anak 64.359.706 jiwa (Kompilasi Data Departemen Sosial 2009).

Pekerja sosial disini dimaksudkan sebagai aktivitas professional yang bertujuan untuk menolong individu, kelompok, dan masyarakat dalam meningkatkan atau memperbaiki kapasitas mereka agar berfungsi sosial dan menciptakan kondisi kondisi masyarakat yang kondusif untuk mencapai tujuan tersebut. Pekerja sosial dituntut untuk melakukan advokasi terhadap $\mathrm{ABH}$ agar hak-haknya dapat terpenuhi sesuai dengan UU SPPA. Selain itu, secara spesifik peran pekerja sosial dibutuhkan dalam proses diversi. Bersama-sama dengan anak, orangtua atau wali, korban, pembimbing kemasyarakatan, pekerja sosial melakukan musyawarah untuk mencapai kesepakatan seadil-adilnya dalam kasus yang dihadapi. Peran pekerja sosial yang lebih besar harus diikuti dengan peningkatan kualitas maupun kuantitas. Secara kualitas dituntut memiliki pengetahuan dan keterampilan terkait isu $\mathrm{ABH}$ misalnya, pemahamannya tentang UU SPPA, UU Perlindungan Anak dan UU terkait. Tentang keterampilan misalnya, pekerja sosial harus dibekali dengan kemampuannya dalam mengatasi klien yang mengalami trauma dan bagaimana mengatasinya. Dari kuantitas, secara otomatis dibutuhkan jumlah pekerja sosial yang lebih besar dalam mengatasi $\mathrm{ABH}$. Peningkatan kualitas maupun kuantitas pekerjaan sosial bisa dilakukan dengan meningkatkan penyelenggaraan pendidikan pekerjaan sosial yang selama ini sudah ada di beberapa perguruan tinggi, selain itu juga bisa dilakuian pelatihan yang dapat menunjang pengetahuan pekerja sosial terkait $\mathrm{ABH}$.

\section{B. JENIS PENELITIAN}

Berdasarkan tujuan penelitiannya, penelitian ini termasuk ke dalam penelitian deskriptif. Dalam penelitian deskriptif, gambaran atau fenomena suatu realitas sosial yang kompleks dapat dihasilkan secara lebih spesifik dan mendetail (Neuman, 2006, h. 35). Penelitian deskriptif dapat berupa kuantitatif, kualitatif, maupun kombinasi keduanya. (Usman dan Akbar, 2008, h. 130). Diantara ketiga jenis tersebut, penelitian ini termasuk penelitian deskriptif kualitatif. Karakteristik penelitian kualitatif dilakukan pada kondisi alamiah, langsung ke sumber data dan peneliti sebagai instrument, lebih bersifat deskriptif, lebih menekankan pada proses daripada produk, analisa data secara induktif, dan lebih menekankan pada makna (Sugiyono, 2005, h. 143) Penelitian sosial yang menggunakan format deskriptif kualitatif bertujuan untuk menggambarkan meringkaskan berbagai kondisi, berbagai situasi atau fenomena realitas sosial yang ada di masyarakat yang menjadi obyek penelitian. Pada jenis penelitian deskriptif kualitatif, data yang dikumpulkan berupa kata-kata, gambar, dan bukan angka-angka. Dengan demikian laporan penelitian akan berisi kutipan-kutipan data untuk memberi gambaran penyajian laporan tersebut. Data 
tersebut mungkin berasal dari naskah, wawancara, catatan lapangan, foto, video tape, atau dokumentasi resmi lainnya (Moleong, 2000, h. 6). Penelitian jenis ini untuk memperoleh keleluasaan dalam menggambarkan permasalahan secara sistematis, faktual dan akurat mengenai situasi yang ada di lapangan. Dengan jenis penelitian ini, peran-peran yang dijalankan oleh pekerja sosial dalam penerapan restorative justice dan hambatan-hambatan yang dialami dalam menjalankan peran tersebut akan lebih mudah terjabarkan dan dipahami.

\section{ISI}

Manusia dalam hidup bermasyarakat, akan saling berhubungan dan saling membutuhkan satu sama lain. Kebutuhan itulah yang dapat menimbulkan suatu proses interaksi sosial. Kata interaksi secara umum dapat diartikan saling berhubungan atau saling bereaksi dan terjadi pada dua orang induvidu atau lebih. Sedangkan sosial adalah berkenaan dengan masyarakat (Wiyono, 2007:234). Oleh karena itu secara umum interaksi sosial dapat diartika sebagai hubungan yang terjadi dalam sekelompok induvidu yang saling berhubungan baik dalam berkomunikasi maupun melakukan tindakan sosial.

Interaksi sosial merupakan pula salah satu prinsip integritas kurikulum pembelajaran yang meliputi keterampilan berkomunikasi, yang bekerja sama yang dapat untuk menumbuhkan komunikasi yang harmonis antara individu dengan lingkungannya (Hernawan, 2010:314). Berdasarkan pendapat tersebut dapat dipahami bahwa interkasi sosial sangat penting diberikan sebagai pengetahuan kepada siswa sejak dibangku sekolah, karena berkenaan dengan keterampilan berkomunikasi dan kerja sama yang dapat menumbuhkan sikap siswa setelah terjun kemasyarakat kelak.

(Max Weber dalam Hernawan, 2010:14), menjelaskan bahwa tindakan interaksi sosial adalah tindakan seorang individu yang dapat mempengaruhi individu- individu lainnya dalam lingkungan sosial. Dalam bertindak atau berperilaku sosial,seorang individu

hendaknya memperhitungkan keberadaan individu lain yang ada dalam lingkungannya. $\mathrm{Hal}$ tersebut penting diperhatikan karena tindakan interaksi sosial merupakan perwujudan dari hubungan atau interaksi sosial.

Bentuk interaksi sosial yang terjadi antara dua orang atau lebih yang akan berdampak pada sifat seorang individu yang dapat mempengaruhi sebuah perubahan yang terjadi dalam diri seseorang. Artinya dalam interaksi sosial terdapat hubungan yang dilakukan oleh manusia baik secara individu maupun kelompok, yang merupakan hubungan yang dilakukan oleh manusia untuk bertindak terhadap sesuatu atas dasar makna yang dimiliki oleh manusia. Dengan demikian makna interaksi,kemudian makna yang dimiliki oleh manusia itu berasal dari interaksi antara seseorang dengan sesamanya.

Interaksi sosial secara konkret, meupakan interaksi sosial yang dapat dipahamioleh semua manusia sejak lahir,karena pada dasarnya kehidupan manusia tidak terlepas dari lingkungan dimana dia berada. Di lingkungan tersebut manusia saling berkomunikasi dan berinterakasi, sehingga secara tidak sadar manusia telah melakukan interaksi sosial. Interaksi sosial tersebut kemudian menjadi ciri khas sikap dan perilaku manusia dalam lingkungan.

Interaksi sosial dapat dilihat pada kehidupan sehari-hari termasuk kita sendiri, yang kita ketahui, bukan saja di pengaruhi oleh kemampuan dalam intelektual individu. Karena manusia itu sendiri senantiasa melakukan hubungan yang dapat mempengaruhi hubungan timbal balik antara manusia yang satu dengan yang lain,dalam rangka memenuhi kebutuhan dalam mempertahankan kehidupannya. Bahkan secara ekterm manusia akan mempunyai arti jika ada manusia yang lain tempat untuk berinteraksi.

$\begin{array}{lcr}\text { Interaksi } & \text { sosial bermula dari } \\ \text { perasaan-persaaan } & \text { ketidakadilan yang } \\ \text { dirasakan oleh } & \text { sekelompok orang. } \\ \text { Ketidakadilan ini menimbulkan perasaan } & \text { mankan } \\ \text { benci, marah dan bermusuhan. Dalam hal ini } \\ \text { keadilan memang merupakan sesuatu yang }\end{array}$


relatif sifatnya, yang hanya tergantung pada nilai-nilai yang dianut,dalam orientasi hidup individu di tentukan oleh situasi dan kondisi tertentu. Dalam kehidupan seharihari,individu tidak bisa lepas dari interaksi sosial. Setinggi apapun kemandirian seorang induvidu, tetap akan membutuhkan orang lain.

Berdasarkan pengertian tersebut, maka dapat dijelaskan bahwa interaksi sosial merupakan tingkat kemampuan yang dimiliki oleh siswa dalam melakukan hubungan baik antara rekan-rekannya, antara siswa dan guru maupun siswa dengan orang tuanya, baik dalam menerima, maupun menolak dan menilai komunikasi yang diperoleh dalam bentuk proses interaksi. Interaksi sosial seseorang sesuai dengan tingkat keberhasilan dalam menjalin sebuah hubungan yang dinyatakan dalam bentuk prialaku sosial yang baik,yang dapat diketahui setelah diadakan evaluasi.

Anak merupakan bagian yang tidak terpisahkan dari kehidupan suatu masyarakat. Anak adalah makhluk sosial seperti juga orang dewasa. Anak membutuhkan orang lain untuk dapat membantu mengembangkan kemampuannya, karena anak lahir dengan segala kelemahan sehingga tanpa orang lain anak tidak mungkin dapat mencapai taraf kemanusiaan yang normal.

Pengertian anak secara umum dipahami masyarakat adalah keturunan kedua setelah ayah dan ibu. Sekalipun dari hubungan yang tidak sah dalam kaca mata hukum. Ia tetap dinamakan anak, sehingga pada definisi ini tidak dibatasi dengan usia. Sedangkan dalam pengertian Hukum Perkawinan Indonesia, anak yang belum mencapai usia 18 tahun atau belum pernah melangsungkan perkawinan ada di bawah kekuasaan orang tuanya. Selama mereka tidak dicabut dari kekuasaan. Pengertian ini bersandar pada kemampuan anak, jika anak telah mencapai umur 18 tahun, namun belum mampu menghidupi dirinya sendiri, maka ia termasuk katagori anak. Namun berbeda apabila ia telah melakukan perbuatan hukum, maka ia telah dikenai peraturan hukum atau perUndang-Undangan.
Anak menurut Undang-Undang Kesejahteraan Anak adalah seseorang yang belum mencapai umur 21 tahun dan belum pernah kawin. Dalam perspektif UndangUndang Peradilan Anak, anak adalah orang yang dalam perkara anak nakal telah mencapai umur 8 (delapan) tahun tetapi belum mencapai umur 18 tahun dan belum pernah kawin. Sementara dalam Kompilasi Hukum Islam pasal 98 (1) dikatakan bahwa batas usia anak yang mampu berdiri sendiri atau dewasa adalah usia 21 tahun, sepanjang anak tersebut tidak bercacat fisik maupun mental atau belum pernah melangsungkan perkawinan. Adapun pengertian anak menurut Pasal 45 KUHP adalah orang yang belum cukup umur, yaitu mereka yang melakukan perbuatan (tindak pidana) sebelum umur 16 (enam belas) tahun

Sedangkan dalam Konvensi Hak Anak (KHA), anak adalah setiap manusia yang berusia dibawah 18 tahun, kecuali berdasarkan Undang-Undang yang berlaku bagi anak yang ditentukan bahwa usia dewasa telah mencapai lebih awal. Dengan demikian pasal ini mengakui bahwa batas usia kedewasaan dalam aturan hukum sebuah Negara mungkin berbeda dengan ketentuan KHA. Dalam kasus ini Komite Hak Anak menekankan agar Negara meratifikasi KHA menyelaraskan peraturan-peraturan hukumnya dengan KHA. Dari pengertian ini tidak terlihat permulaan atau dimulainya status anak. Apakah sejak anak tersebut lahir, ataukah sejak anak tersebut masih dalam kandungan ibunya. Dalam hal ini KHA tidak menyebutkan secara tegas. Tetapi dalam bagian mukadimah, dinyatakan bahwa anak dikarenakan ketidakmatangan jasmani dan mentalnya memerlukan pengamanan dan pemeliharaan khusus termasuk perlindungan hukum yang layak sebelum dan sesudah kelahirannya. Pada prinsipnya pokok pikiran yang harus dipegang adalah bahwa Negara yang meratifikasi KHA harus memajukan dan melindungi kepentingan dan hak anak sebagai manusia hingga mereka bisa mencapai kematangan mental dan fisik.

Anak mempunyai hak-hak yang secara spesifik berbeda dengan manusia dewasa karena kondisi fisik dan mentalnya yang belum stabil. Dalam banyak hal, anak- 
anak memerlukan perlakuan dan perlindungan khusus, terutama terhadap perbuatan yang bisa merugikan perkembangannya maupun masyarakat. Anak membutuhkan pihak lain seperti keluarga, masyarakat, pemerintah dan negara untuk mendukung tumbuh kembang anak secara wajar. Kesejahteraan dan perlindungan anak merupakan persoalan yang serius karena terkait dengan kelangsungan hidup sebuah masyarakat dan rancang bangun sosial masa depan sebuah negara (Supeno, 2010, h. 31). Konvensi Hak Anak (KHA) merupakan instrumen yang penting terkait hak anak karena sifatnya yang mengikat secara hukum bagi semua anggota Perserikatan BangsaBangsa (PBB) yang telah meratifikasinya dan mulai diberlakukan sejak 2 September 1990. KHA terdiri atas 54 pasal yang berdasarkan materi hukumnya mengatur tentang hak-hak anak yang dapat dikelompokkan dalam empat kategori, yaitu :

1. Hak terhadap kelangsungan hidup, yang meliputi hak untuk mempertahankan hidup, hak untuk memperoleh standar kesehatan tertinggi, dan perawatan yang sebaikbaiknya.

2. Hak terhadap perlindungan, yaitu hak perlindungan dari diskriminasi, tindak kekerasan, dan ketelantaran.

3. Hak untuk tumbuh kembang yang meliputi hak anak akan pendidikan dan hak untuk mencapai standar hidup yang layak bagi perkembangan fisik, mental, spiritual, moral, dan sosial.

4. Hak untuk berpartisipasi, yaitu hak anak untuk menyatakan pendapat atas segala hal yang mempengaruhi kehidupannya.

Istilah Anak yang Berhadapan dengan Hukum (ABH) sangat terkait dengan kenakalan anak atau yang sering disebut dengan juvenile deliquency. Sebagaimana halnya pengertian anak, pengertian kenakalan atau delikuensi juga beragam. Istilah delikuensi berasal dari delinquency dan pada umumnya bergandengan dengan kata juvenile sehingga dalam bahasa Indonesia sering diterjemahkan sebagai kenakalan anak, kenakalan remaja, atau kenakalan pemuda. Kartono (1998) mengemukakan bahwa juvenile delikuency adalah perilaku jahat atau kejahatan/kenakalan anak- anak muda yang merupakan gejala sakit (patologis) secara sosial pada anak dan remaja yang disebabkan oleh satu bentuk tingkah laku yang menyimpang (h. 6).

Bartollas (1985) mengemukakan ada beberapa faktor yang menjadi latar belakang karakteristik pribadi anak yang berisiko tinggi menjadi pelaku deliquency, yaitu umur (anak yang lebih muda akan berisiko lebih tinggi), variabel psikologis (sifat membantah, susah diatur, merasa kurang dihargai), school performance (bermasalah di sekolah dengan tingkah lakunya, membolos), home adjustment (kurang interaksi dengan orang tua dan saudara, kurang disiplin dan pengawasan, minggat), pengguna alkohol dan obat terlarang, lingkungan tetangga, dan adanya pengaruh kekuatan teman sebaya (Marlina, 2009, h. 61).

Secara konseptual, Unicef (2004) menyatakan bahwa anak yang berhadapan dengan hukum (children in conflict with the law) dimaknai sebagai seseorang yang berusia di bawah 18 tahun yang berhadapan dengan sistem peradilan pidana dikarenakan yang bersangkutan disangka atau dituduh melakukan tindak pidana. Di Indonesia batasan usia untuk pertanggungjawaban pidana sesuai ketentuan UU No. 3 tahun 1997 adalah 8 tahun sampai umur 18 tahun dan belum pernah kawin. Penetapan usia 8 tahun sebagai titik asumsi batas minimum di Indonesia dianggap terlalu rendah karena dalam hukum kebiasaan internasional (international customary law), batas minimal usia pertanggung jawab pidana adalah 12 tahun (YPHA, 2010, h. 19).

Perlindungan terhadap anak yang berhadapan dengan hukum telah diatur dalam beberapa instrumen hukum internasional antara lain Peraturan Standar PBB tentang Administrasi Peradilan Bagi Anak (Beijing Rules), Konvensi Hak Anak, Pedoman PBB dalam rangka Pencegahan Tindak Pidana Anak (Riyadh Gidelines), dan Resolusi PBB tentang Administrasi Peradilan Anak (Vienna Guidelines), dan Aturan Minimum PBB mengenai Tindakan Non Penahanan (Tokyo 
Rules). Dari sekian banyak instrumen hukum tersebut, Supeno (2010) telah merangkumnya dalam tiga belas prinsip sebagai manifestasi dari hak anak dalam sistem peradilan, yaitu pelaku adalah korban; pertimbangan kepentingan anak; tidak mengganggu tumbuh kembang anak; penghargaan pendapat anak; prinsip adil dan setara; menjunjung harkat dan martabat; kepastian hukum; pencegahan kenakalan anak; mindset pengadilan; pemidanaan sebagai upaya terakhir; perhatian khusus kelompok rentan; pendekatan peka gender; dan tidak ada penjara anak (h. 90-119)

Berdasarkan peraturan perundang undangan yang berlaku di Indonesia secara yuridis, batasan usia kapan seseorang dikategorikan anak terjadi dualisme.Satu pihak menetapkan anak adalah seseorang yang berusia di bawah 21 tahun, dipihak lain menetapkan anak adalah seseorang yang berusia di bawah 18 tahun. Dalam sistem perundang-undangan kita belum ada unifikasi tentang hukum anak, akan tetapi sudah terkodifikasi dalam beberapa peraturan perundang-undangan yang berlaku saat ini. Undang-Undang memberikan pengetian anak lebih menitik beratkan pada pembatasan usia. Untuk lebih jelasnya penulis menyajikan beberapa pengertian Hukum Anak yang sudah terkodifikasi.

Salah satu persoalan yang serius dan mendesak untuk memperoleh perhatian adalah penanganan Anak yang Berhadapan dengan Hukum (ABH). Dimensi berhadapan dengan hukum berarti adanya tindakantindakan anak yang bertentangan dengan ketentuan- ketentuan hukum yang berlaku dan sah di Indonesia, sehingga dalam konteks ini dapat didefinisikan bahwa anakanak yang bermasalah dengan hukum anakanak yang belum dewasa menurut hukum dan melakukan tindakan- tindakan yang bertentangan dengan hukum yang berlaku dan sah.

Umumnya anak- anak yang berhadapan dengan hukum didefinisikan sebagai anak yang disangka, didakwa atau dinyatakan bersalah melanggar ketentuan hukum atau seorang anak yang diduga telah melakukan atau telah ditemukan melakukan suatu pelanggaran hukum. Dalam kepustakaan hukum, $\mathrm{ABH}$ disebutkan bahwa
Anak yang berhadapan dengan hukum adalah anak yang telah mencapai usia 12 (dua belas) tahun tetapi belum mencapai usia 18 (delapan belas) tahun dan belum menikah:

a) Yang diduga, disangka, didakwa, atau dijatuhi pidana karena melakukan tindak pidana;

b) Yang menjadi korban tindak pidana atau yang melihat dan/atau mendengar sendiri terjadinya suatu tindak pidana.

Anak yang berhadapan dengan hukum dapat juga dikatakan sebagai anak yang terpaksa berkontak dengan sistem pengadilan pidana karena :

a) Disangka, didakwa, atau dinyatakan terbukti bersalah melanggar hukum

b) Telah menjadi korban akibat perbuatan pelanggaran hukum tang dilakukan orang/kelompok orang/lembaga/negara terhadapnya; atau

c) Telah melihat, mendengar, merasakan, atau mengetahui suatu peristiwa pelanggaran hukum.

Ada dua kategori perilaku anak yang membuat ia harus berhadapan dengan hukum :

a. Status Offence, Yaitu perilaku kenakalan anak yang apabila dilakukan orang dewasa tidak dianggap kejahatan, misal: membolos sekolah, kabur dari rumah, dll.

b. Juvunile Delequency; Yaitu perilaku kenakalan anak yang apabila dilakukan orang dewasa dianggap kejahatan atau criminal. misal; perampokan, memperkosa, pelecehan seksual, dll

Oleh karena itu jika dilihat ruang lingkupnya maka anak yang berhadapan dengan hukum dapat dibagi menjadi :

a) Pelaku atau tersangka tindak pidana;

b) Korban tindak pidana;

c) Saksi suatu tindak pidana 
Dalam memahami Anak yang Berhadapan dengan Hukum $(\mathrm{ABH})$ terdapat beberapa hal penting yang saling berkaitan , yaitu :

a. Pelaku kerap menjadi sarana pelampiasan kemarahan masyarakat yang merasa tercoreng rasa keadilannya.

b. Hukum beserta aparat penegak hukumnya berusaha untuk memenuhi rasa keadilan masyarakat dengan memproses kasus pidana yang dilakukan oleh anak tersebut.

c. Sebagai seorang anak, mekanisme hukum dan rasa keadilan masyarakat harus ditempatkan dalam kerangka yang mendorong secara konstruktif ke arah perkembangan fisik dan psikisnya.

Dalam berbagai literatur yang membahas tentang anak dan kejahatan, ada dua pendekatan dalam penanganan terhadap anak yang berhadapan dengan hukum, yaitu pendekatan kesejahteraan (Welfare model) dan pendekatan keadilan (Justice Model) (Jamrozik, 2001, h. 239). Pendekatan keadilan yang sering juga disebut dengan pendekatan hukum menekankan pada tanggung jawab penuh pelaku atas tindak kejahatan yang telah dilakukannya (Kratcoski, 2004, h. 6), sedangkan pendekatan kesejahteraan menekankan pada kesejahteraan dan pembinaan bagi anak pelaku kejahatan demi memenuhi kebutuhan setiap individu anak (Harkrisnowo, 1993, h. 57). Pendekatan keadilan dan kesejahteraan ini sejalan dengan dua macam perlakuan yang diberikan kepada anak yang melakukan tindak kejahatan, yaitu "dihukum" (Punishment) atau "pembinaan" (Treatment) (Kratcoski, 2004, h. 6). Dalam pendekatan keadilan, anak yang melakukan tindak kejahatan akan diberi perlakuan berupa hukuman, sementara dalam pendekatan kesejahteraan, anak yang melakukan tindakan kejahatan akan diberi intervensi berupa pembinaan untuk terpenuhinya kebutuhan individu anak.

Zastrow (2004) menguraikan kedua tipe perlakuan ini dalam beberapa jenis tindakan. Dalam perlakuan tipe menghukum, ada beberapa jenis hukuman yang diberikan kepada anak yang melakukan tindak kejahatan, yaitu

1. Physical Torture (penyiksaan fisik). Bentuk hukuman ini biasanya diterapkan dalam komunitas. Hukuman ini antara lain berupa hukuman cambuk, kurungan, dipukul, diberi cap atau tanda dengan besi panas, melakukan kerja paksa, dipelintir, dan mutilasi.

2. Social Humuliation (penghinaan sosial)Jenis hukuman ini adalah menurunkan status sosial terhukum di tengah masyarakat. Cara ini digunakan di Eropa pada abad ke-16 dan 17. Teknis penghukumannya sangat beragam salah satu diantaranya yaitu dengan mengikat pelaku di tiang yang dipancangkan di tengah perkampungan dan selanjutnya warga bebas mencaci maki atau menghujat pelaku.

3. Financial Penalties. Hukuman ini adalah adanya kewajiban bagi pelaku untuk membayar sejumlah uang sebagai ganti rugi atau denda atas kejahatan yang telah dilakukan. Dalam jenis hukuman ini akan timbul masalah jika pelaku adalah anak yang berasal dari keluarga miskin atau kurang mampu secara ekonomi. Alternatif untuk masalah tersebut biasanya adalah mewajibkan anak untuk melakukan pekerjaan dengan upah yang setara dengan nilai ganti rugi yang harus dibayarkannya.

4. ExileHukuman ini dilakukan dalam bentuk pengasingan atau pembuangan ke tempat yang cukup jauh dari daerah asal pelaku. Jenis hukuman ini biasa dipraktekkan pada abad ke-16 dan 17. Salah satu contoh yang paling umum adalah Inggris yang membuang para pelaku kriminal ke Australia dan Selandia Baru.

5. Death PenaltyPada jenis ini hukuman yang diberikan adalah hukuman mati yang dapat dilakukan dengan metode eksekusi yang beragam, seperti digantung, ditembak, dibakar, dipancung, diracun, dan berbagai metode lain. Hukuman mati biasanya dijatuhkan pada kejahatan-kejahatan 
yang "luar biasa" dan biasanya disertai dengan penghilangan nyawa orang. Hukuman mati sampai saat ini masih menjadi kontroversi dan perdebatan oleh banyak pihak. Jenis hukuman ini juga sangat jarang atau hampir tidak pernah dijatuhkan pada anak.

6. ImprisonmentHukuman ini adalah hukuman berupa penjara, termasuk juga di dalamnya penjara seumur hidup. Dewasa ini jenis hukuman inilah yang umum diberikan kepada para pelaku tindak kejahatan (h. 330334).

Manusia memiliki fungsi sosialnya masing-masing, terutama dalam berinteraksi dengan sesama manusia karena pada dasarnya manusia adalah makhluk sosial yang artinya adalah tidak bisa terlepas dari orang lain, sehingga membutuhkan sesama manusia lainnya. Menurut Undang-undang Republik Indonesia Nomor 11 tahun 2009 tentang Kesejahteraan Sosial, "kesejahteraan sosial adalah kondisi terpenuhinya kebutuhan material, spiritual, dan sosial warga negara agar dapat hidup layak dan mampu mengembangkan diri, sehingga dapat melaksanakan fungsi sosialnya". Dalam hal ini kesejahteraan sosial dipahami sebagai sebuah kondisi.

Sementara itu Zastrow (2004) menyatakan bahwa kesejahteraan sosial pada dasarnya dapat dipahami dalam dua konteks, yaitu sebagai sebuah institusi dan sebagai sebuah disiplin akademi. Sebagai institusi kesejahteraan sosial dapat dipahami sebagai program pelayanan maupun pertolongan untuk memenuhi kebutuhan masyarakat. Sedangkan sebagai sebuah disiplin ilmu, kesejahteraan sosial mengacu pada studi terhadap lembaga, program, maupun kebijakan yang fokus pada pelayanan masyarakat (h. 5). Dalam konteks yang inilah istilah kesejahteraan sosial sering dipertukarkan dengan pekerjaan sosial meskipun merujuk pada satu maksud yang sama (Huda, 2009, h. 74). Pada dasarnya keduanya memiliki ruang lingkup yang berbeda. Kesejahteran sosial lebih luas daripada pekerjaan sosial, dimana kesejahteraan sosial meliputi bidang pekerjaan sosial (Huda, 2009, h. 81).
Pekerjaan sosial merupakan sebuah aktivitas professional dalam menolong individu, kelompok, dan masyarakat dalam meningkatkan atau memperbaiki kapasitas mereka agar berfungsi sosial dan untuk menciptakan kondisi-kondisi masyarakat yang kondusif dalam mencapai tujuannya (Zastrow, 2004, h. 5). Pekerjaan sosial memfokuskan intervensinya pada proses interaksi antara manusia dengan lingkungannya dengan menggunakan teoriteori perilaku manusia dan sistem sosial guna meningkatkan taraf hidup masyarakat. Pekerjaan sosial berawal dari pembahasan yang bersifat mikro, baru kemudian dalam perkembangannya bergerak ke arah mezzo, atau lebih dikenal dengan level komunitas atau organisasi. $\mathrm{Di}$ sisi lain, ilmu kesejahteraan sosial diawali dengan upaya untuk memahami suatu fenomena dari konteks makro, masyarakat dalam arti luas tanpa melupakan aspek mikro persoalan tersebut.

Pelayanan sosial merupakan salah satu bentuk dari kebijakan sosial yang merupakan aksi atau tindakan untuk mengatasi masalah sosial. Pelayanan sosial dapat diartikan sebagai seperangkat program yang ditujukan untuk membantu individu atau kelompok yang mengalami hambatan dalam memenuhi kebutuhan hidupnya. Bidang pelayanan sosial yang banyak mendapat perhatian pekerjaan sosial adalah pelayanan sosial personal yang mencakup tiga jenis, yaitu :

1. Perawatan anak Diberikan terhadap anak-anak dan keluarganya, khususnya anak yang memiliki kebutuhan khusus.

2. Perawatan masyarakat (community care) Merupakan pelayanan rehabilitasi berbasis masyarakat sebagai alternatif dari pelayanan yang diberikan lembaga. Pelayanan umumnya diberikan di rumah atau di lingkungan masyarakat bagi mereka yang mengalami gangguan fisik atau mental yang memerlukan penanganan professional selain bantuan dari keluarga atau .warga masyarakat setempat.

3. Peradilan kriminalDalam sistem peradilan kriminal, pekerja sosial 
memiliki peranan yang cukup penting. Mereka biasanya disebut sebagai pekerja sosial koreksional. Dalam hal ini pekerja sosial terlibat dalam penanganan masalah kriminal, termasuk terhadap anak-anak yang melakukan pelanggaran hukum. Selain melakukan assesmen dan pendampingan sosial pada tahap probasi dan parole, pekerja sosial juga dapat memberikan pelayanan konseling atau terapi psikososial bagi narapidana yang ada di dalam penjara atau terhadap mantan narapidana yang telah kembali ke masyarakat (Suharto, 2008, h. 20).

Dalam bekerja dengan anak, seorang pekerja sosial harus memahami bagaimana proses perkembangan anak, apa yang mereka butuhkan dari lingkungannya, dan bagaimana mereka bereaksi jika kebutuhan tersebut tidak dapat mereka peroleh (Brandon, et al., 1998, h. 3). Dengan memahami ciri-ciri perkembangan anak dan dipadukan dengan kondisi sosial anak maka pekerja sosial akan dapat menetnukan bagaimana perlakuan yang akan diberikan pada anak. Selain itu seorang pekerja sosial yang bekerja dengan anak, juga harus mampu menjalin hubungan yang baik dengan orang-orang yang terdekat anak, seperti orang tua atau keluarga, guru, atau teman dekat (O'Loughlin and O'Loughlin, 2008, h. 5). Dengan mereka pekerja sosial dapat mendiskusikan tentang kondisi anak dan mengupayakan agar dapat bekerja sama dalam memberikan situasi yang lebih baik bagi anak (Mabey and Sorensen, 1995, h. 57).

Peranan pekerjaan sosial dalam hal perlindungan terhadap anak yang berhadapan dengan hukum pada beberapa literatur disebutkan bahwa pekerja sosial pada umumnya bekerja dalam setting koreksional. Zastrow (2004) menyatakan bahwa fokus utama pekerjaan sosial dalam sistem peradilan pidana adalah pada komponen koreksional. Dalam hal ini ada berbagai peran yang dapat dilakukan oleh pekerja sosial dalam menangani $\mathrm{ABH}$. Pekerja sosial dapat bekerja sebagai petugas probasi dan parole, pekerja sosial di lingkungan penjara, pekerja sosial pada half way house (rumah singgah), dan sebagai petugas yang memberi layanan sosial bagi individu atau keluarga yang oleh karena kasusnya harus berhubungan dengan polisi dan aparat hukum lainnya (h. 340).

Dalam penanganan pelaku anak, pekerja sosial dapat berperan sebagai investigator, yaitu melakukan wawancara terhadap orang tua, anak, dan pihak lain yang terkait dengan kasus anak seperti orang-orang dari lingkungan sekolah atau polisi. Hasil wawancara atau investigasi ini dapat digunakan membantu aparat hukum untuk menentukan kelanjutan kasus apakah akan dihentikan atau iteruskan. Hasil investigasi ini juga dapat digunakan sebagai bahan pertimbangan untuk menyusun atau membuat rencana treatment apa yang akan diberikan pada anak. Selain itu pekerja sosial juga dapat berperan sebagai konselor, petugas parole dan probasi, atau bahkan sebagai saksi ahli dalam sidang-sidang yang melibatkan tersangka anak (Crosson-Tower, 2007, h. 266-267).

Selain itu, beberapa peran pekerja sosial dalam penanganan $A B H$, yaitu sebagai petugas parole dan probasi; perencana, pelaksana, dan supervis program rehabilitasi $\mathrm{ABH}$; dan manajer dalam lembaga rehabilitasi $A B H$. Pekerja sosial yang juga memiliki gelar dalam bidang hukum dapat juga bekerja sebagai hakim anak (Ginsberg, 1998, h. 144147).

Sementara itu Ambrosino (2001) memberikan peran yang lebih beragam bagi pekerja sosial yang bekerja dalam sistem peradilan pidana dan penanganan anak yang berhadapan dengan hukum. Peran-peran tersebut antara lain membantu polisi dalam proses investigasi dan wawancara terhadap anak; manajer program rehabilitasi anak; sebagai pengajar; sebagai konselor bagi anak; petugas probasi dan parole; menjadi pendamping bagi saksi dan korban; merancang program rehabilitasi bagi anak; dan membantu mencari pekerjaan atau tempat tinggal sementara bagi anak yang baru keluar dari tahanan atau penjara ( $h$. 458-459).

Mengingat peran keluarga dalam pembentukan karakter atau kepribadian anak sangat penting melalui interaksi anak didalam 
keluarga, dan karena jumlah anak nakal/berhadapan dengan hukum cenderung meningkat dari tahun ke tahun, maka diperlukan kajian mendalam untuk mengetahui faktor-faktor interaksi di dalam keluarga yang berperan dalam mendorong atau memicu perilaku anak menjadi nakal/berhadapan dengan hukum. Hal ini sangat penting untuk mengantisipasi perubahan norma dan nilai yang ada di masyarakat, yang mempengaruhi interaksi didalam keluarga dan yang menyebabkan terjadinya masalah penyimpangan perilaku pada anak. Dengan diketahuinya interaksi di dalam keluarga yang cenderung memicu kenakalan anak, maka kajian ini diharapkan bermanfaat bagi pengembangan program penanganan anak nakal dan atau berhadapan dengan hukum, baik melalui lembaga maupun luar lembaga (keluarga dan masyarakat), khususnya untuk mencegah terjadinya permasalahan perilaku pada anak.

\section{PUSTAKA}

Abu Huraerah, M.Si. 2006. Kekerasan Terhadap Anak: Fenomena Masalah Sosial Kritis di Indonesia. (Bandung: Nuansa)

Al-Istanbull, Mahmud Mahdi 2002, Mendidik Anak Nakal. Bandung: Pustaka.

Convention on the Right of thr Child (Konvensi Hak Anak), pasal 2 ayat (2), dalam M. Joni dan Zulchaina Z Tanamas, Aspek Hukum Perlindungan Anak dalam Perspektif Konvensi Hak Anak, cet. Ke-I (Bandung: Citra Aditya Bakti, 1999)

Diyanayati, Kissumi, 2009. Perilaku Menyimpang Remaja Akibat Perceraian Orangtua Yogyakarta : B2P3KS Press.

Gerungan. 2010. Psikologi Sosial. Bandung: Refika Aditama.

Gultom, Maidin. Perlindungan Hukum Terhadap Anak dalam Sistem Peradilan Pidana Anak di Indonesia, Refika Aditama, Bndung, 2008.
Hermawan, Didik . (2009). "Pengaruh Interaksi Sosial Terhadap Prestasi Belajar. Sampel dalam penelitian ini adalah seluruh siswa kelas IV SD Negeri Damar Wulan 1 Kepung yang berjumlah 39 siswa". (http://digilid.ac.id/) (Diakses pada 27 Maret 2015)

Kartono, Kartini.1992. "Patologi Sosial 2 Kenakalan Remaja". Jakarta. Rajawali Pers

Luhpuri, Dorang dan satriawan. 2004. Modul Diklat Pekerjaan Sosial Koreksional. Bandung: Balai besar pendidikan dan penelitian kesejahteraan sosial Bandung.

Muhidin,

Syarif.1997. "Pengantar Kesejahteraan Sosial". Bandung: Sekolah Tinggi Kesejahteraan Sosial.

Nipan Halim, Anak Saleh Dambaan Keluarga, (Yogyakarta: Mitra Pustaka, 2001), hlm. 21.

M. Z. Lawang, Robert. 1994. Teori Sosiologi Klasik dan Modern. Jakarta : Gramedia Pustaka Utama

Rusmana, Aep. 2012. Perlindungan Sosial Anak Yang Berkonflik Dengan Hukum. Jurnal Ilmiah Pekerjaan Sosial. Vol. 11

Soekanto, Soerjono. 2005. Sosiologi Suatu Pengantar. Jakarta: PT RajaGrafindo Persada.

Sugito. 1994.Interaksi Dalam Keluarga sebagai Dasar Pengembangan Kepribadian Anak. Cakrawala Pendidikan Nomor 2, Tahun XIII

Wiyono, A. S., Aspek Psikologi pada Implementasi Sistem Teknologi Informasi: Proceeding of Konferensi dan Temu Nasional Teknologi Informasi dan Komunikasi untuk Indonesia, Jakarta : e-Indonesia Initiative, 2008.

Zastrow, Charles H, 1999, The Practice of SocialWork, USA:ColePublishing Co. 